The stronger chapters of the book are those in which Billingham highlights the atypical infanticides in which married women and men are the perpetrators. These chapters provide more original research and analysis than her earlier chapters. Billingham's final chapter, which she labels an epilogue, is a welcome, if brief, connection to modern ideas and concerns about infanticide. Here Billingham more than accomplishes her goal of demonstrating that certain themes of early modern society are still incredibly relevant: motivations are mixed; the search for responsibility expands to include a community; parental and communal feelings toward fetuses and newborns can be highly ambiguous. Billingham questions and then pinpoints why infanticide was and remains a topic of morbid interest in a variety of media: the innocence of the victim "frees writers to use the crime as the basis for discussing other matters" (318).

While Billingham's original contribution from primary sources remains limited to a hundred cases in Sussex, her greater contribution is connecting several disciplines' analyses of infanticide in early modern England, proposing much wider-reaching theories about motivation and societal and cultural context and meaning, as well as painting an image of the mentality of the perpetrators of this crime. Even if some of her proposals are reaching too far, Billingham does build scholars a much larger scaffolding of analysis for future work.

Margaret B. Lewis, University of Tennessee at Martin doi: $10.1017 /$ rqx.2021.47

\title{
Invisible Agents: Women and Espionage in Seventeenth-Century Britain. Nadine Akkerman. \\ Oxford: Oxford University Press, 2018. xxii + 264 pp. + color pls. \$26.95.
}

This richly illustrated, scrupulously researched book offers case studies of six Royalist spies, as well as a chapter on women who worked on the parliamentary side. As Akkerman shows, Royalists were more willing to rely on women than Parliamentarians, and Royalist spies tended to be of relatively high status, so they were on equal footing with their handlers. In contrast, Parliamentary spies were on the Council of State's payroll, sometimes as nurses. The book introduces players who will be new to many readers but also provides fresh perspectives on figures as familiar as Aphra Behn, Anne Halkett, and Charles I. Filled with arresting discoveries, it is above all a model of assessing received wisdom critically and returning to the archive to look anew at material letters and the secrets they still keep.

For example, Akkerman scrutinizes how Elizabeth Murray's story has usually been told, and then carefully unpicks that narrative. She tracks down the original of Elizabeth Carey, Lady Mordaunt's “spiritual diary," presumed lost, and by doing so identifies passages missing from an otherwise perfect nineteenth-century transcription; she then draws on these newly discovered passages to support her argument that Lady 
Mordaunt carefully shaped her account of herself "to come to terms with the sinful life she led as a she-intelligencer" (179). Similarly, Akkerman reads Anne, Lady Halkett's "true account" less as an apology for marrying someone who was already married, which Halkett doesn't seem especially apologetic about, and more as an apology for her spying activities — especially her role in helping James, Duke of York, the future James II, dress as a woman and escape. It was rumored at the time that this escape might have served a scheme to replace the future Charles II with his brother and so establish a Catholic succession. This is why Anne might later have felt she had to explain herself.

Akkerman shows how complex the operations of gender were. Women could serve as "invisible agents" because they were so readily underestimated and ignored. Marriage might have served as a cover for some, although it could also render them vulnerable $(61,67,80-81)$; by changing their names, coverture also makes it more difficult to trace them. While women could sometimes use sex to their advantage, they were also vulnerable to being dismissed as sexually suspect, not only by contemporaries but also by subsequent historians. As Akkerman shows, we have sometimes overestimated or invented the importance of sex in these women's lives and narratives; we have also sometimes missed it. Some of Akkerman's most delicious discoveries emerge out of careful rereadings of archival documents that yield new understandings of a single sentence, even a single word. For instance, in her discussion of Charles I's relationship to Jane Harwood, who helped him in several escape attempts, she finds the supposedly uxorious and pious Charles promising Jane "a swyving," formerly decoded as "answering" (56).

What Akkerman does not find is as interesting as what she does. Akkerman's point that women do not seem to have been punished for espionage, even if caught, is provocative. The one agent who pays with her life here is Susan Hyde, who seems to have died from rough treatment by Cromwell. She was the sister of Edward Hyde, first Earl of Clarendon, lord chancellor under Charles II; as the father of Anne Hyde, James II's first wife, he was also the grandfather of two Stuart queens, Mary and Anne, although he died years before that unexpected development. Yet Hyde never mentions his sister's contribution to the Royalist cause or her death. Akkerman makes us notice that silence.

While Akkerman makes a provocative suggestion that drowning was used to execute women, as well as men convicted of sodomy, because it disappears rather than displays their bodies, she supports her claim with a source describing punishments in Europe, not Britain. The question she raises is an important one, perhaps even more so given that women were subjected to various spectacular punishments in seventeenth-century Britain, including the pillory, hanging, and burning, for offenses from theft to murder to treason. Why, then, did most of these invisible agents escape punishment? Were women being spared or dismissed? Was the state protecting them or protecting itself from admitting women's roles as "she-intelligencers"?

Frances E. Dolan, University of California, Davis doi: $10.1017 /$ rqx.2021.48 